\title{
Studies on Physical Changes during Fruit Growth and Development of Different Genotypes of Ber (Zizyphus mauritiana L.)
}

\author{
Kumudani Sahu, C.S. Pandey*, S.K. Pandey and Rinku Verma \\ Department of Horticulture, College of Agriculture, JNKVV, \\ Jabalpur - 482 004, (M.P.), India \\ *Corresponding author
}

\section{A B S T R A C T}

\section{Keywords \\ Ber genotype, \\ Physical changes, \\ Growth and development \\ Article Info \\ Accepted: \\ 22 January 2019 \\ Available Online: \\ 10 February 2019}

The present investigation was carried out during the year 2017-2018 at the Fruit research station Imalia, and in laboratory of Department of Horticulture/Food Science, College of Agriculture, Jawaharlal Nehru Krishi Vishwa Vidyalaya, Jabalpur (M.P.). The experiment was laid out in Completely Randomized Design (CRD) with four replication comprising six different genotypes of ber (treatment) viz., Gola, Banarasi karaka, Umran, Jawahar ber1, Jawahar ber-2, Jawahar ber-3. It was found that the various physical parameters viz. fruit weight, fruit volume, fruit length, fruit diameter, pulp weight, stone weight, pulp stone ratio were found to be increased during the entire course(30 days to 180 days) of growth and development period. Among the various genotypes, Umran was found the best genotype in respect to the highest average weight per fruit $(27.50 \mathrm{~g})$, size of $4.18 \times 3.18$ $\mathrm{cm}$, pulp to stone ratio (23.55), yield $(68.106 \mathrm{~kg}$ per tree) with an attractive chocolate colour and good taste at maturity.

\section{Introduction}

Ber (Zizyphus mauritania Lamk.) is one of the most ancient and common fruit indigenous to India and belongs to family Rhamnaceae. The genus Zizyphus includes about fifty species of which about 18 to 20 are native to India (Pareek, 1983). Being xerophytic, ber is an important fruit crop of arid and semi-arid regions. Ber is previously recognized as poor man's fruit, also designated as "King of Arid fruits" owing to fact that it can be grown in unproductive, waste, marginal or inferior soil with $\mathrm{pH}$ as high as 9.0 in arid and semi-arid regions. Its cultivation dates back to vedic times. It grows on all types of soils except very saline and heavy clay soils and is resistant to drought, heat and frost (Sinko, 1971). It can be grown on marginal lands generally unsuitable for cultivation of other horticultural and agronomic crops. Ber requires less water than other fruit crop. It is thus, much more suited to dryland farming.

It is, thus, popularly called as a desert apple'. It can successfully be cultivated even in the most marginal ecosystems of the sub-tropics and tropics (Pareek, 2001). Ber is popular due to high economic returns, low cost of cultivation, wider adaptability and ability to withstand drought. The ber grows on variety of soils from gravelly, shallow to deep aridisols. 
The ber is distributed worldwide including the Indian sub-continent, South-east Asia, Australia, China, Africa, Mediterranean region and American centre but its cultivation is confined over drier part of the globe and the main cultivation occurs in India. Rajasthan, Haryana, Uttar Pradesh, Gujarat, Madhya Pradesh, Bihar, Maharashtra, Andhra Pradesh and Tamil Nadu are the major ber growing states of the India. The area and production of Ber in India is reported 49 Thousand ha. and 526 Thousand MT, respectively (Anonymous, 2016-17). Ber is one of the most nutritious fruits and have medicinal and processing potential. Despite of all these attributes, the crop remained neglected for a long time and the area expansion is not at a desirable speed. Lack of the knowledge in respect of superior varieties and their adaptability in different agro-climatic zones appear to be the main hurdle in the expansion of area.

Reviewing the merits there is considerable scope for improvement by thoroughly screening some genotypes for their growth behaviour to select or recommend superior varieties to the farmers. Variation in yield as well as physical and chemical properties of fruits of different ber varieties has been reported by several workers. The information on pattern of physical changes during growth and development of ber fruits are scanty and it is an essential factor to evaluate the different genotype. Plant growth, yield and physicochemical attributes are important parameters to study the variability among the different genotype of ber fruit crop. Therefore, the present investigation has been under taken with objective to study the pattern of fruit growth and development in different genotypes of ber.

\section{Materials and Methods}

The experiment was conducted at the Fruit research station Imalia, the biochemical analysis of fruits and organoleptic evaluation were carried out at the laboratories of Department of Horticulture and Food Science Technology, College of Agriculture Jawaharlal Nehru Krishi Vishwa Vidyalaya Jabalpur during the year 2017-18. The experiment was laid out in Completely Randomized Design (CRD) with four replication comprising six different genotypes of ber (treatment) viz, Gola, Banarasi karaka, Umran, Jawahar ber-1, Jawahar ber-2, Jawahar ber-3. From each treatment, 5 fruit were selected and evaluated at an interval of 30 days. Length and width of fruit was measured with the help of vernier calipers. The average weight of the fruit was calculated by dividing the total weight of fruits with the number of fruits weighed. Fruits were placed in measuring cylinder of 1 liter capacity filled with water. The replaced water was measured and the data were recorded as volume of fruits in $\mathrm{ml}$ then average value was computed. The specific gravity of the fruit was determined by weighing fruits from each treatment of each replication in top pan balance and then recording displaced water after sinking fruits in water. The specific gravity was calculated by dividing the weight of fruit with the volume of fruit. For pulp weight, five fruits were weighed and the pulp was extracted and weighed in gram. For stone weight, weight of each stone was measured and average weight of stones was worked out. The pulp stone ratio was worked out by dividing the weight of pulp with the weight of stone.

\section{Results and Discussion}

\section{Length of fruit (cm)}

The data pertaining to the length $(\mathrm{cm})$ of ber fruits as influenced by different genotype during growth and development stages (Table 1) revealed that length of fruit of different ber genotypes have been found to be increased with advancement of growth and development 
period. The maximum $(1.87 \mathrm{~cm})$ fruit length was recorded in Umran and the minimum $(1.44 \mathrm{~cm})$ in Gola at 30 days. The maximum $(2.74 \mathrm{~cm})$ fruit length was recorded in Umran and the minimum $(1.57 \mathrm{~cm})$ in Jawahar ber-3 at 60 days. The maximum $(3.37 \mathrm{~cm})$ fruit length was observed in Umran followed by Banarasi karaka (3.09) and the minimum (1.85 $\mathrm{cm})$ in Jawahar ber-3 at 90 days. The maximum $(3.54 \mathrm{~cm})$ fruit length was noted in Umran and minimum (2.49) in Jawahar ber-3 at 120 days.

The maximum $(4.18 \mathrm{~cm})$ fruit length was noted in Umran and the minimum (2.63) in Jawahar ber-2 at 150 days. At 180 days, fruiting season was over in all genotype except Jawahar ber-3 which recorded fruit length $(2.78 \mathrm{~cm})$. These findings are similar to the report of Pareek (2001), Kumar et al., (1987), Kundi et al., (1989). Faroda (1996), Akhundova and Agaev (1989), Reddy et al., (1998), Ram et al., (2008).

\section{Width of fruit (cm)}

The data relevant to the width $(\mathrm{cm})$ of ber fruits as influenced by different genotype during growth and development stages (Table 2) showed that width of fruit of different ber genotype have been found to be increased with advancement of growth and development period. The maximum $(1.21 \mathrm{~cm})$ width was recorded in Gola and minimum $(0.92 \mathrm{~cm})$ in Banarasi karaka at 30 days. The maximum $(1.80 \mathrm{~cm})$ fruit width was found in Gola and the minimum $(1.06 \mathrm{~cm})$ in Jawahar ber-3 at 60 days. The maximum $(2.11 \mathrm{~cm})$ fruit width was observed in Umran and the minimum (1.38 $\mathrm{cm})$ in Jawahar ber-3 at 90 days. The maximum $(3.13 \mathrm{~cm})$ fruit width was seen in Umran and the minimum $(1.76 \mathrm{~cm})$ in Jawahar ber-3 at 120 days. The maximum $(3.18 \mathrm{~cm})$ fruit width was noted in Umran. at 150 days. At 180 days, fruiting season was over in all genotype except Jawahar ber-3 which recorded the width of $(2.53 \mathrm{~cm})$. These findings are Dhanumjaya Rao and Subramanyam (2010), Jan Brindza et al., (2011), Ganesh Shukla et al., (2012). Muhammad et al., (2013) and Mohsin Abbas et al., (2012).

\section{Weight of fruit (g)}

The data subjected to the periodical weight (g) of ber fruits as influenced by genotypes during growth and development stages (Table 3) revealed that the weight of fruit was significantly influenced by different ber genotype and has been found to be increased with advancement of growth and development period. The maximum (3.10 g) weight of fruit was recorded in Gola, while the minimum $(1.75 \mathrm{~g})$ was in Umran at 30 days.

The maximum $(5.40 \mathrm{~g})$ weight of fruit was recorded in Gola while the minimum (2.98 g) was in Jawahar ber-3 at 60 days. The maximum (16.15 g) was found in Gola while the minimum $(5.14 \mathrm{~g})$ was in Jawahar ber-3 at 90 days. The maximum (26.68 g) was in Gola while the minimum (7.68 g) was in Jawahar ber-3 at 120 days. The maximum (27.50 g) weight was found in Umran while minimum (12.66 g) was in Jawahnar ber-3 at 150 days. The only one genotype Jawahar ber-3 was found to have fruit at 180 days with fruit weight $(21.82 \mathrm{~g})$. Akhundova and Agaev (1989), Reddy et al., (1998), Ram et al., (2008)

\section{Volume of fruit (ml)}

The data with respect to the periodical volume (ml) of ber fruit as influenced by different genotypes during their growth and development stages (Table 4) showed that volume of fruit of different ber genotypes have been found to be increased with advancement of growth and developmental period from 30days to 150days. 
Table.1 Periodical length $(\mathrm{cm})$ of ber fruit as influenced by different genotypes during their growth and development stages

\begin{tabular}{|l|c|c|c|c|c|c|}
\hline \multirow{2}{*}{\multicolumn{1}{|c|}{ Genotypes }} & \multicolumn{7}{|c|}{ Days After Fruit Setting (DAFS) } \\
\cline { 2 - 8 } & $\mathbf{3 0}$ & $\mathbf{6 0}$ & $\mathbf{9 0}$ & $\mathbf{1 2 0}$ & $\mathbf{1 5 0}$ & $\mathbf{1 8 0}$ \\
\hline Gola & 1.44 & 2.07 & 2.50 & 2.84 & - & - \\
\hline Banarasi karaka & 1.67 & 2.44 & 3.09 & 3.47 & 3.51 & - \\
\hline Umran & 1.87 & 2.74 & 3.37 & 3.54 & 4.18 & - \\
\hline Jawahar ber -1 & 1.69 & 1.94 & 2.54 & 2.69 & - & - \\
\hline Jawahar ber -2 & 1.58 & 1.81 & 2.09 & 2.58 & 2.63 & - \\
\hline Jawahar ber- 3 & - & 1.57 & 1.85 & 2.49 & 2.72 & 2.78 \\
\hline SEm \pm & 0.10 & 0.11 & 0.11 & 0.11 & 0.10 & 0.04 \\
\hline C.D.5\% level & 0.30 & 0.33 & 0.33 & 0.32 & 0.30 & 0.13 \\
\hline
\end{tabular}

Table.2 Periodical width $(\mathrm{cm})$ of ber fruit as influenced by different genotypes during their growth and development stages

\begin{tabular}{|l|c|c|c|c|c|c|c|}
\hline \multirow{2}{*}{ Genotypes } & \multicolumn{7}{|c|}{ Days After Fruit Setting (DAFS) } \\
\cline { 2 - 7 } & $\mathbf{3 0}$ & $\mathbf{6 0}$ & $\mathbf{9 0}$ & $\mathbf{1 2 0}$ & $\mathbf{1 5 0}$ & $\mathbf{1 8 0}$ \\
\hline Gola & 1.21 & 1.80 & 2.06 & 2.73 & - & - \\
\hline Banarasi karaka & 0.92 & 1.18 & 1.79 & 2.18 & 2.23 & - \\
\hline Umran & 1.09 & 1.71 & 2.11 & 3.13 & 3.18 & - \\
\hline Jawahar ber -1 & 1.20 & 1.63 & 2.07 & 2.63 & - & - \\
\hline Jawahar ber -2 & 1.02 & 1.39 & 1.84 & 2.35 & 2.44 & - \\
\hline Jawahar ber- 3 & - & 1.06 & 1.38 & 1.76 & 2.51 & 2.53 \\
\hline SEm \pm & 0.10 & 0.11 & 0.12 & 0.11 & 0.09 & 0.04 \\
\hline C.D.5\% level & 0.30 & 0.33 & 0.37 & 0.33 & 0.27 & 0.12 \\
\hline
\end{tabular}

Table.3 Periodical weight ( $\mathrm{g}$ ) of ber fruit as influenced by different genotypes during their growth and development stages

\begin{tabular}{|l|c|c|c|c|c|c|c|}
\hline \multirow{2}{*}{ Genotypes } & \multicolumn{7}{|c|}{ Days After Fruit Setting (DAFS) } \\
\cline { 2 - 8 } & $\mathbf{3 0}$ & $\mathbf{6 0}$ & $\mathbf{9 0}$ & $\mathbf{1 2 0}$ & $\mathbf{1 5 0}$ & $\mathbf{1 8 0}$ \\
\hline Gola & 3.10 & 5.40 & 16.15 & 26.68 & - & - \\
\hline Banarasi karaka & 2.06 & 3.88 & 5.48 & 10.14 & 14.86 & - \\
\hline Umran & 1.75 & 3.96 & 10.50 & 21.10 & 27.50 & - \\
\hline Jawahar ber -1 & 2.66 & 4.70 & 8.42 & 11.80 & - & - \\
\hline Jawahar ber -2 & 2.12 & 4.64 & 8.15 & 10.44 & 16.26 & - \\
\hline Jawahar ber- 3 & - & 2.98 & 5.14 & 7.68 & 12.66 & 21.82 \\
\hline SEm \pm & 0.09 & 0.20 & 0.18 & 1.01 & 0.94 & 0.44 \\
\hline C.D.5\% level & 0.27 & 0.61 & 0.54 & 3.03 & 2.83 & 1.32 \\
\hline
\end{tabular}


Table.4 Periodical volume (ml) of ber fruit as influenced by different genotypes during their growth and development stages

\begin{tabular}{|l|c|c|c|c|c|c|}
\hline \multirow{2}{*}{ Genotypes } & \multicolumn{7}{|c|}{ Days After Fruit Setting (DAFS) } \\
\cline { 2 - 7 } & $\mathbf{3 0}$ & $\mathbf{6 0}$ & $\mathbf{9 0}$ & $\mathbf{1 2 0}$ & $\mathbf{1 5 0}$ & $\mathbf{1 8 0}$ \\
\hline Gola & 3.06 & 5.70 & 10.86 & 12.44 & - & - \\
\hline Banarasi karaka & 2.37 & 3.74 & 6.34 & 9.58 & 10.06 & - \\
\hline Umran & 1.63 & 8.72 & 13.64 & 24.46 & 30.32 & - \\
\hline Jawahar ber -1 & 2.06 & 2.86 & 4.34 & 5.18 & - & - \\
\hline Jawahar ber -2 & 3.18 & 5.30 & 7.16 & 9.04 & 10.34 & - \\
\hline Jawahar ber- 3 & - & 2.62 & 4.76 & 8.72 & 9.20 & 11.33 \\
\hline SEm \pm & 0.17 & 0.54 & 0.88 & 1.08 & 0.88 & 0.35 \\
\hline C.D.5\% level & 0.50 & 0.54 & 2.65 & 3.25 & 2.64 & 1.05 \\
\hline
\end{tabular}

Table.5 Periodical specific gravity of ber fruit as influenced by different genotypes during their growth and development stages

\begin{tabular}{|l|c|c|c|c|c|c|c|}
\hline \multirow{2}{*}{ Genotypes } & \multicolumn{7}{|c|}{ Days After Fruit Setting (DAFS) } \\
\cline { 2 - 7 } & $\mathbf{3 0}$ & $\mathbf{6 0}$ & $\mathbf{9 0}$ & $\mathbf{1 2 0}$ & $\mathbf{1 5 0}$ & $\mathbf{1 8 0}$ \\
\hline Gola & 1.01 & 0.94 & 1.49 & 2.14 & - & - \\
\hline Banarasi karaka & 1.07 & 0.45 & 0.76 & 0.86 & 0.90 & - \\
\hline Umran & 0.86 & 1.06 & 0.86 & 1.05 & 1.22 & - \\
\hline Jawahar ber -1 & 1.29 & 1.64 & 1.94 & 2.27 & - & - \\
\hline Jawahar ber -2 & 0.66 & 0.87 & 1.16 & 1.15 & 1.57 & - \\
\hline Jawahar ber- 3 & - & 1.13 & 1.07 & 0.88 & 1.37 & 1.97 \\
\hline SEm \pm & 0.08 & 0.10 & 0.10 & 0.11 & 0.11 & 0.04 \\
\hline C.D.5\% level & 0.25 & 0.30 & 0.30 & 0.33 & 0.33 & 0.13 \\
\hline
\end{tabular}

Table.6 Periodical pulp weight (g) of ber fruit as influenced by different genotypes during their growth and development stages

\begin{tabular}{|l|c|c|c|c|c|c|}
\hline \multirow{2}{*}{ Genotypes } & \multicolumn{7}{|c|}{ Days After Fruit Setting (DAFS) } \\
\cline { 2 - 7 } & $\mathbf{3 0}$ & $\mathbf{6 0}$ & $\mathbf{9 0}$ & $\mathbf{1 2 0}$ & $\mathbf{1 5 0}$ & $\mathbf{1 8 0}$ \\
\hline Gola & 2.69 & 4.72 & 14.85 & 25.39 & - & - \\
\hline Banarasi karaka & 1.53 & 3.14 & 4.63 & 9.01 & 13.22 & - \\
\hline Umran & 1.40 & 3.43 & 9.79 & 20.18 & 26.38 & - \\
\hline Jawahar ber -1 & 2.36 & 4.21 & 7.71 & 10.92 & - & - \\
\hline Jawahar ber -2 & 1.87 & 4.23 & 7.47 & 9.59 & 14.59 & - \\
\hline Jawahar ber-3 & - & 2.60 & 4.62 & 6.97 & 11.80 & 20.85 \\
\hline SEm & 0.10 & 0.09 & 0.43 & 0.99 & 0.65 & 0.44 \\
\hline C.D.5\% level & 0.32 & 0.27 & 1.29 & 2.97 & 1.95 & 1.32 \\
\hline
\end{tabular}


Table.7 Periodical weight of stone ( $\mathrm{g}$ ) of ber fruit as influenced by different genotype during their growth and development stages

\begin{tabular}{|c|c|c|c|c|c|c|}
\hline \multirow[t]{2}{*}{ Genotypes } & \multicolumn{6}{|c|}{ Days After Fruit Setting (DAFS) } \\
\hline & 30 & 60 & 90 & 120 & 150 & 180 \\
\hline Gola & 0.41 & 0.64 & 1.10 & 1.29 & - & - \\
\hline Banarasi karaka & 0.53 & 0.74 & 0.85 & 1.13 & 1.64 & - \\
\hline Umran & 0.35 & 0.53 & 0.71 & 0.92 & 1.12 & - \\
\hline Jawahar ber -1 & 0.30 & 0.49 & 0.71 & 0.91 & - & - \\
\hline Jawahar ber -2 & 0.25 & 0.41 & 0.68 & 0.85 & 1.83 & - \\
\hline Jawahar ber- 3 & - & 0.38 & 0.52 & 0.71 & 0.86 & 0.97 \\
\hline SEm \pm & 0.03 & 0.10 & 0.10 & 0.11 & 0.09 & 0.04 \\
\hline C.D. $5 \%$ level & 0.09 & N.S. & 0.30 & 0.33 & 0.27 & 0.13 \\
\hline
\end{tabular}

Table.8 Periodical pulp stone ratio $(\%)$ of ber fruit as influenced by different genotype during their growth and development stages

\begin{tabular}{|l|c|c|c|c|c|c|}
\hline \multirow{2}{*}{ Genotypes } & \multicolumn{7}{|c|}{ Days After Fruit Setting (DAFS) } \\
\cline { 2 - 7 } & $\mathbf{3 0}$ & $\mathbf{6 0}$ & $\mathbf{9 0}$ & $\mathbf{1 2 0}$ & $\mathbf{1 5 0}$ & $\mathbf{1 8 0}$ \\
\hline Gola & 6.56 & 7.43 & 12.07 & 19.68 & - & - \\
\hline Banarasi karaka & 2.88 & 4.24 & 5.44 & 7.97 & 8.06 & - \\
\hline Umran & 3.99 & 6.47 & 13.78 & 21.93 & 23.55 & - \\
\hline Jawahar ber -1 & 7.85 & 8.59 & 10.82 & 11.99 & - & - \\
\hline Jawahar ber -2 & 7.51 & 10.32 & 10.98 & 11.28 & 7.92 & - \\
\hline Jawahar ber- 3 & - & 6.83 & 8.88 & 9.81 & 13.72 & 21.49 \\
\hline SEm \pm & 0.09 & 0.09 & 0.64 & 0.16 & 0.17 & 0.04 \\
\hline C.D.5\% level & 0.29 & 0.27 & 1.82 & 0.48 & 0.50 & 0.12 \\
\hline
\end{tabular}

Jawahar ber- 2 recorded the maximum $(3.18$ $\mathrm{ml})$ volume and was found to be at par with Gola (3.06 ml) whereas; Umran had minimum $(1.63 \mathrm{ml})$ volume at 30 days.

However, the maximum volume $(8.72 \mathrm{ml}$, $13.64,24.46$ and $30.32 \mathrm{ml}$ ) was recorded in Umran, followed by Gola $(5.70,10.86,12.44 \mathrm{ml})$ at $60,90,120$ days respectively.

Jawahar ber-3 recorded volume $(11.33 \mathrm{ml})$.at 180 days, whereas, no other genotypes were found in fruiting condition. Our findings are also in line reported by Dhanumjaya Rao and Subramanyam (2010), Jan Brindza et al., (2011), Ganesh Shukla et al., (2012).

\section{Specific gravity}

The data pertaining to the specific gravity of ber fruit as influenced by different genotypes during their growth and development stages (Table 5) has been found to be greatly influenced with different genotypes of ber at each stage of growth and development period. The maximum (1.29) specific gravity observed was in Jawahar ber-1 whereas; Jawahar ber-2 had minimum (0.66) specific gravity at 30 days. The maximum (1.64) specific gravity was found in Jawahar ber-1 whereas, Banarasi karaka had minimum (0.45) specific gravity at 60 days. The maximum (1.94) specific gravity was notted in Jawahar ber-1 with minimum in Banarasi 
karaka (0.76) at 90 days. At 120 days,the maximum (2.27) specific gravity was observed in Jawahar ber-1, whereas minimum in Banarasi karaka (0.86).The maximum (1.57) specific gravity was found in Jawahar ber-1, having minimum in Banarasi karaka (0.90) at 150 days. At 180 days, no other genotypes were found in fruiting condition except Jawahar ber-3, which recorded the specific gravity (1.97)

\section{Pulp weight (g)}

The data pertaining to the periodical change in pulp weight $(\mathrm{g})$ of ber fruits as influenced by different genotype during growth and development stages (Table 6) revealed that pulp weight of fruit of different ber genotype have been found to be increased with advancement of growth and development period. The maximum $(2.69 \mathrm{~g})$ pulp weight was recorded in Gola and the minimum (1.40 g) Umran at 30 days. The maximum (4.72 g) pulp weight was found in Gola and the minimum $(2.60 \mathrm{~g})$ in Jawahar ber-3 at 60 days. The maximum (14.85 g) pulp weight was found in Gola and the minimum (6.62 g) in Jawahar ber-3 at 90 days. The maximum $(25.39 \mathrm{~g})$ fruit pulp was in Gola followed by Umran $(20.18 \mathrm{~g})$ and minimum (6.97 g) Jawahar ber-3 at 120 days. The maximum $(26.38 \mathrm{~g})$ pulp weight Umran and minimum (11.80 g) Jawahar ber-3 at 150 days. At 180 days, it was $(20.85 \mathrm{~g})$ in Jawahar ber-3. The findings are in line of Dhanumjaya Rao and Subramanyam (2010).

\section{Weight of stone (g)}

The data with respect to the weight of stone (g) of ber fruits as influenced by different genotype during growth and development stages are presented in (Table 7) revealed that weight of stone of fruit of different ber genotype have been found to be increased with advancement of growth and development period. The maximum $(0.53 \mathrm{~g})$ weight of stone was observed in Banarasi karaka and the minimum $(0.25 \mathrm{~g})$ in Jawahar ber- 2 at 30 days. The maximum $(0.74 \mathrm{~g})$ weight of stone was found in Banarasi karaka and the minimum $(0.38 \mathrm{~g})$ in Jawahar ber-3 at 60 days. At 90 and 120 days, the maximum (1.10 $\mathrm{g}$ and $1.29 \mathrm{~g}$ ) weight of stone was recorded in Gola and the minimum $(0.52$ and $0.71 \mathrm{~g})$ in Jawahar ber-3. The maximum (1.83 g) weight of stone was found in Jawahar ber-2 and minimum $(0.86 \mathrm{~g})$ in Jawahar ber-3. at 150 days. At 180 days Jawahar ber-3 recorded $(0.97 \mathrm{~g})$ stone weight. The findings are in line of Singh Rajesh and Misra (2012).

\section{Pulp stone ratio}

The data pertaining to the pulp stone ratio (\%) of ber fruits as influenced by different genotypes during growth and development stages (Table 8.) showed that pulp stone ratio of fruit of different ber genotype have been found to be increased with advancement of growth and development period. The maximum (7.85) pulp stone ratio was found in Jawahar ber -1 and the minimum (2.88) in Banarasi karaka at 30 days. At 90 days, the maximum (10.32) pulp stone ratio was recorded in Jawahar ber -2 and minimum (4.24) in Banarasi karaka at 60 days. The maximum (12.07) pulp stone ratio was in found in Gola and minimum (5.44) in Banarasi karaka. The maximum (21.93) pulp stone ratio was found in Umran and the minimum (7.97) in Banarasi karaka at 120 days. The maximum (23.55) pulp stone ratio was in Umran and the minimum (7.92) in Jawahar ber- 2 at 150 days. At 180 days, it was 21.49 in jawahar ber-3. The results are in the line of finding by Dhingra et al., (1973) and Akhundova and Agaev (1989) reported the ratio of pulp to stone in Gola was 0.14 and in Mundia 0.23. Mohsin Abbas (2012) recorded highest stone size $(2.09 \mathrm{~cm} 2)$ and stone weight $(2.31 \mathrm{~g})$ in Foladi. However, 
maximum flesh ratio (10.59 \%) was in Gorh genotype. Similar observations were also recorded by Jan Brindza et al., (2011).

\section{References}

Akhundova, N.I. and Agaev, K.K. 1989. Diversity of jujube in lowland Karabakh and its utilization. (In Russian) Subtropicheskie Kul'tury. 6:105-107.

Anonymous 2017. Horticulture Statistics at a Glance.

Dhanumjaya Rao, K. and Subramanyam, K. 2010. Evaluation of yield performance of ber varieties under scarce rainfallzone. Agric. Sci. Digest, 30 (1): $57-59$.

Faroda, A.S. 1996. Developed resistance to fruit fly in ber through hybridization.

Ganesh, Shukla, Rekha Singh, R.B., Ram and Deepa, H.D. 2012. Genetic variability and correlation Analysis in Ber (Ziziphus mauritiana Lamk.)Germplasm in Lucknow. Hortflora Res. Spectrum. 1(2):122-126.

ICAR News Sci. and Technol. Newsletter. 2(4): 23.

Jan Brindza., Margita, K., Olga, G., Vladimir, V., Lucia, K. and Gabriela, E. 2011. Morphological and organoleptic nature of Ziziphus jujuba Mill. 5: 4.

Kumar, P.S. and Babu, R.S. 1987. Physicochemical characters of some ber (Ziziphus mauritiana Lamk.) cultivars grown at Hyderabad. Dept. Hort. Coll. Agric. Punjab Hort. J. 27(1-2):17-21.

Kundi, A.H.K., Wazir, F.K., Addul, G. and Wazri, Z.D.K. 1989. Physico-chemical characteristics and organoleptice valuation of different ber (Ziziphus jububa Mill.) cultivar Sarhad J. Agric. 5:149-155

Mohsin, A. Malik Sharif, Naseem Ahmad, M. and Tanweer. 2012. Quality evaluation of promising ber (Zizyphus mauritiana. Lamk.) varieties under climatic conditions of Faisalabad. J. Agric. Res. 5(3): 401.

Neog, M., Mohan, N.K. and Baruna, P.C. 1993. Physico-chemical changes during growth and development of local ber (Ziziphus jujube Mill.) fruits of Assam. Haryana J. Hort. Sci. 22(1): 121-125.

Pareek, O.P. 2001. Ber. International Centre for underutilized crops, Southampton, U.K. pp. 248-266.

Pareek, O.P. and Vashishtha, B.B. 1983. Delicious ber varieties of Rajasthan. Indian Hort. 28(2): 13-15.

Ram, R.B., Ganesh, S., Deepa, H., Dwivedi. and Abdul, K. 2008. Physico-chemical studies on ber (Zizyphus mauritiana. Lamk) germplasm under sodic soil conditions of Lucknow. Indian $\mathrm{J}$. Agroforestry. 10(1): 78-80.

Reddy, B.G.M., Patil, D.R., Kulkarni, N.G. and Patil, S.G.1998. Economic performance of selected ber varieties. Karnataka J. Agric. Sci. 11(2): 538-539.

Singh, R. and Misra, K.K. 2012. Studies on physico-chemical characters of fruits of Ber (Zizyphus mauritiana Lamk.) genotypes. Prog. Hort. 43(2): 248-251.

Sinko, L.T. 1971. Jujube, one of the most valuable subtropical fruit crops in the South Soviet Union. Trudy Gosudarstvennogo Niksitkogo Botanicheskogo Sada. 52: 31-53.

\section{How to cite this article:}

Kumudani Sahu, C.S. Pandey, S.K. Pandey and Rinku Verma. 2019. Studies on Physical Changes during Fruit Growth and Development of Different Genotypes of Ber (Zizyphus mauritiana L.). Int.J.Curr.Microbiol.App.Sci. 8(02): 3325-3332.

doi: https://doi.org/10.20546/ijcmas.2019.802.387 